\title{
Transatlantica
}

Revue d'études américaines. American Studies Journal

1 | 2017

Morphing Bodies: Strategies of Embodiment in

Contemporary US Cultural Practices

\section{Kathy Knapp, American Unexceptionalism. The Everyman and the Suburban Novel after 9/11}

\section{Sophie Vallas}

\section{(2) OpenEdition}

\section{Journals}

Electronic version

URL: https://journals.openedition.org/transatlantica/9249

DOI: $10.4000 /$ transatlantica.9249

ISSN: 1765-2766

Publisher

Association française d'Etudes Américaines (AFEA)

Electronic reference

Sophie Vallas, "Kathy Knapp, American Unexceptionalism. The Everyman and the Suburban Novel after

9/17", Transatlantica [Online], 1 | 2017, Online since 16 October 2018, connection on 21 May 2021. URL: http://journals.openedition.org/transatlantica/9249 ; DOI: https://doi.org/10.4000/transatlantica.9249

This text was automatically generated on 21 May 2021.

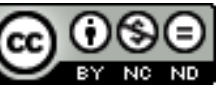

Transatlantica - Revue d'études américaines est mise à disposition selon les termes de la licence Creative Commons Attribution - Pas d'Utilisation Commerciale - Pas de Modification 4.0 International. 


\title{
Kathy Knapp, American Unexceptionalism. The Everyman and the Suburban Novel after 9/11
}

\author{
Sophie Vallas
}

\section{REFERENCES}

Kathy Knapp, American Unexceptionalism. The Everyman and the Suburban Novel after 9/11, Iowa City: University of Iowa Press, 2014, 183 pages, 26,52 \$, ISBN: 978-1-60938-228-5.

1 In American Unexceptionalism. The Everyman and the Suburban Novel After 9/11, Kathy Knapp analyzes the way many American writers have been revisiting (and reviving, she contends) a most American tradition, suburban literature, in the aftermath of the fall of the Twin Towers.

2 In her long, contextualizing introduction, Knapp notes that $50 \%$ of the victims of the World Trade Center attacks were from the suburbs (New York, New Jersey, Connecticut), and that $75 \%$ of them were white middle-class men, figures of this invisible "everyman" that American literature first celebrated in the 1950 s as an alienated, paralyzed antihero trapped in a discourse of victimization while enjoying the white male privilege consciously embedded in those growing, booming suburbs built after the Second World War (Updike, Cheever, Yates...) and then, in the 1990s, as a pitiful, selfish, avaricious coward refusing to take responsibility, either for himself or for others (Gates, Eugenides, Moody...).

3 Many critics, Knapp adds, have underlined the fact that, since 9/11, a large number of novels have tended to go back to staging suburban America and middle-class male protagonists, as a way to face the aftermath of the 2001 crisis without having to deal with the events directly, choosing instead to analyze this new "anxious everyday that is often as banal as it is nerve-wracking" (xiii) by focusing on this familiar space, the suburbs, which have long encapsulated the image of never-ending prosperity and 
family values that the country invented after 1945 and then promoted. Who are those new characters at the heart of those recent novels, she asks, and how does this new literary movement, born in the first years of the 21st century, fit in or reimagine the long suburban tradition?

The book is divided into five chapters: four are devoted to works signed by male authors (Richard Ford's Frank Bascombe Trilogy, Chang-rae Lee's Aloft, Jonathan Franzen's Freedom and Philip Roth's Everyman) while the last chapter focuses on the figure of the everyman in recent fictions by Ann Tyler, Gish Jen and A. M. Homes. All of these writers chose, as their main characters, white males who are either aging, retired or jobless; all of them facing physical decline, illness and approaching death; all of them very much aware of their faults and failures and no longer trying to dismiss or blame their shortcomings on society. They once enjoyed the boom of their social and economic environment, sometimes becoming prominent members of their prosperous communities, but they are now embodiments of this ever-declining white middle class, stranded in multi-racial, impoverished, decaying suburbs. What Knapp intends to show is that, while they seem to go through the same kind of midlife crisis as their $20^{\text {th }}$ century counterparts, the post-9/11 protagonists, in their unexceptionalism, somehow wave their failing, ordinary lives to counter the traditional discourse that promotes the national myth of exceptionalism which so many tried to revive in the wake of $9 / 11$. As plagued by failure, loss and disease as they may be, those men no longer cling to the individualism or the fetishization of property and privacy that characterized the birth and happy development of suburbs (the perfect nest for the American success story). Here, they coldly assess their place in their community: frequently influenced by strong female characters, they now face their mistakes and hold themselves accountable for their own failures and inaction. In the third volume of the trilogy, Ford's Frank Bascombe thus develops an unexpected capacity for compassion and empathy; Jerry Battle, the hero of Aloft, resists the nation's call to overcome the attacks and go back to normalcy by contemplating a gaping, gravelike hole in his backyard, his own ground zero, thus symbolically "excavating the buried historical trauma that provided the shaky foundation for these postwar suburbs in the first place" (26); Franzen's freedom-defender, Walter Berglund, works at creating an environmental preserve and restoring an emotional bond between people around him and their environment; Roth's nameless everyman, who is already dead when the novel begins and whose corpse reappears in the end, realizes the pain he has inflicted on others in his individualistic pursuit of pleasure; and the male heroes of Tyler, Jen and Homes, act hand in hand with female characters and get concretely involved in ethnically diverse communities plagued by poverty and decay.

5 "These novels suggest that in our vulnerability and inevitable decline, we are all intimately connected to and responsible for one another," Knapp concludes (108). In doing so, they debunk the national discourse on much-admired resilient heroes who traditionally fight to remain winners, their eyes fixed on the horizon. The characters Knapp writes about are so declining that they can be seen as already dead, she says, in the image of Roth's anonymous hero who is lying in his grave when his story begins. Faced with the collapse of the tired, worn-out suburban model based on individualism and the obsession for property and profit, they briefly experience compassion and sharing in some late (and illusory?) epiphany. Kathy Knapp's analysis of her corpus is very interesting, and the way she traces the evolution of American suburban literature is especially convincing. The articulation between her main subject and what she calls 
"post-9/11" novels is perhaps more debatable, the now widely used term remaining (as always) rather vague. Defining something new as "post"-something else generally points at a failure or a refusal to tackle the intriguing novelty; and it also amounts to putting this something else in the limelight, positing it as some kind of inevitable and unshakeable standard. The authors dealt with in American Unexceptionalism. The Everyman and the Suburban Novel after 9/11 chose to avoid confronting 9/11 frontally and preferred to measure its impact on the traumatized surrounding suburbs. But Knapp's interpretation of their novels ends up placing the event back into the center of the picture: she scrutinizes the way its devastating blast has unsettled this white, masculine middle class which, the reader may feel, is, in the end, perhaps paradoxically the very embodiment of this American exceptionalism that thousands of pages have been celebrating.

INDEX

Subjects: Recensions

\section{AUTHORS}

SOPHIE VALLAS

Université Aix-Marseille 